\title{
An overview of menopausal oestrogen-progestin hormone therapy and breast cancer risk
}

\author{
SA Lee ${ }^{*, 1}$, RK Ross' and MC Pike' \\ 'Department of Preventive Medicine, Norris Comprehensive Cancer Center, University of Southern California Keck School of Medicine, I44I Eastlake \\ Avenue, Topping Tower 4423, Los Angeles, CA 90033-0800, USA
}

Results from the Women's Health Initiative (WHI) trial support findings from observational studies that oestrogen-progestin therapy (EPT) use is associated with an increase in breast cancer risk. We conducted a meta-analysis using EPT-specific results from the Collaborative Group on Hormonal Factors in Breast Cancer (CGHFBC) pooled analysis and studies published since that report to obtain an overview of EPT use and breast cancer risk. We also assessed risk by histologic subtype of breast cancer, by schedule of the progestin component of EPT, and by recency of use. We estimate that overall, EPT results in a 7.6\% increase in breast cancer risk per year of use. The risk was statistically significantly lower in US studies than in European studies - 5.2 vs $7.9 \%$. There was a significantly higher risk for continuous-combined than for sequential EPT use in Scandinavian studies where much higher total doses of progestin were used in continuous-combined than in sequential EPT. We observed no overall difference in risk for lobular vs ductal carcinoma but did observe a slightly higher risk for current vs past EPT use.

British Journal of Cancer (2005) 92, 2049-2058. doi:I0.1038/sj.bjc.66026I7 www.bjcancer.com

Published online 17 May 2005

(c) 2005 Cancer Research UK

Keywords: meta-analysis; hormone therapy; breast cancer

The Collaborative Group on Hormonal Factors in Breast Cancer (CGHFBC) (1997) pooled data from 51 epidemiologic studies to obtain an overall estimate of breast cancer risk associated with menopausal hormone therapy (HT) use. The risk estimate for oestrogen therapy (ET) use was based on large numbers of cases and controls, but the oestrogen-progestin therapy (EPT) result was not. Since then, a number of statistically powerful studies have evaluated EPT in relation to breast cancer risk. Some of these further evaluated differences in risk by schedule of progestin administration, that is, sequential $v s$ continuous-combined use (Magnusson et al, 1999; Ross et al, 2000; Schairer et al, 2000; Newcomb et al, 2002; Porch et al, 2002; Weiss et al, 2002; Million Women Study, 2003; Olsson et al, 2003; Stahlberg et al, 2004), and in relation to histologic subtype of breast cancer (Schairer et al, 2000; Daling et al, 2002; Newcomb et al, 2002; Newcomer et al, 2003; Ursin et al, 2002; Weiss et al, 2002).

We conducted a meta-analysis of the results reported by the CGHFBC and studies published since that overview through March 2004 to provide a more precise estimate of the risk from EPT and how it is affected by schedule of progestin administration and histologic subtype.

\section{MATERIALS AND METHODS}

We used the Medline database to compile a list of studies subsequent to the CGHFBC report investigating the relationship

*Correspondence: Dr SA Lee; E-mail: sulggile@usc.edu

Received 20 January 2005; revised 23 March 2005; accepted 25 March 2005; published online 17 May 2005 between EPT and incident breast cancer risk using the Medical Subject Headings (MeSH): postmenopausal, oestrogen progestin therapy (or combined therapy), and breast cancer. For this analysis we did not include studies that presented results only for overall HT, nor did we include studies that only evaluated ET use, nor studies only evaluating breast cancer mortality. A total of 22 studies were identified for possible inclusion (Persson et al, 1996, 1997, 1999; Magnusson et al, 1999; Li et al, 2000, 2002, 2003; Moorman et al, 2000; Rockhill et al, 2000; Ross et al, 2000; Schairer et al, 2000; Chen et al, 2002; Daling et al, 2002; Kirsh and Kreiger, 2002; Newcomb et al, 2002; Newcomer et al, 2003; Porch et al, 2002; Ursin et al, 2002; Weiss et al, 2002; Chlebowski et al, 2003; Jernstrom et al, 2003; Million Women Study, 2003; Olsson et al, 2003; Stahlberg et al, 2004). As age at menopause is a critical factor in assessing HT use and breast cancer risk (Pike et al, 1998), we excluded those studies that did not adjust for age at menopause: this criterion excluded five studies (Persson et al, 1997; Moorman et al, 2000; Chen et al, 2002; Li et al, 2002, 2003). We also excluded three studies that did not have information on risk by duration of EPT use (Persson et al, 1996; Li et al, 2000; Newcomer et al, 2003), and the study of Olsson et al (2003) for reasons described in the Discussion section below. We further excluded two studies since the results were based on the same data incorporated into the CGHFBC report (Persson et al, 1999; Rockhill et al, 2000), and the study of Jernstrom et al (2003), because it only provided results for continuous-combined EPT use, and the reason for this was the greater observed effect with such use than with sequential use. Therefore, the results from 10 recent studies and from the CGHFBC pooled analysis were used to obtain an overall assessment of EPT and breast cancer risk (CGHFBC, 1997; Magnusson et al, 1999; Ross et al, 2000; Schairer et al, 2000; 
Kirsh and Kreiger, 2002; Newcomb et al, 2002; Porch et al, 2002; Weiss et al, 2002; Chlebowski et al, 2003; Stahlberg et al, 2004).

In a second analysis, breast cancer risk by histologic subtype (lobular vs ductal) was evaluated in relation to EPT use. Four of the 10 studies had information on histology (Schairer et al, 2000; Daling et al, 2002; Newcomb et al, 2002; Ursin et al, 2002); Ursin et al (2002) used data from the study of Ross et al (2000) and Daling et al (2002) from the study of Weiss et al (2002). No information was available by histologic subtype from the CGHFBC report.

In a third analysis, we assessed breast cancer risk by progestin schedule (sequential, i.e. oestrogen given alone during the first part of a monthly cycle followed by oestrogen combined with a progestin for the remainder of the cycle with possibly a short hormone-free interval, $v s$ continuous-combined, i.e. oestrogen and progestin always administered together during a cycle). No information was available by progestin schedule from the CGHFBC report on EPT use and breast cancer risk. Seven of the 10 studies had data subdivided by progestin schedule of EPT use (Magnusson et al, 1999; Ross et al, 2000; Newcomb et al, 2002; Porch et al, 2002; Weiss et al, 2002; Million Women Study, 2003; Stahlberg et al, 2004). However, two of these seven studies did not assess duration of use in relation to schedule and were omitted from this analysis (Newcomb et al, 2002; Porch et al, 2002).

As so few studies provided information on past HT use, we were limited in our ability to assess the difference in risk by recency of use. Of the 11 studies included in the overall analysis, four studies presented results comparing risk for past $v s$ current HT use (Magnusson et al, 1999; Newcomb et al, 2002; Weiss et al, 2002; Million Women Study, 2003). Of these, three studies assessed risk by duration of past and current HT use and were included in the analysis (Magnusson et al, 1999; Weiss et al, 2002; Million Women Study, 2003), but only the study by Weiss et al (2002) reported risk for EPT use exclusively; the other two studies (Magnusson et al, 1999; Million Women Study, 2003) reported risk by past combined EPT and ET use.

Log odds ratios (LORs) per year of use $\left(\mathrm{LOR}_{1}\right)$ and $95 \%$ confidence intervals $(\mathrm{CI})$ were calculated for each study using the meta-analytic methods described by Greenland (Rothman and Greenland, 1998). The model fitted is log-linear in duration of EPT. (The hazard ratios calculated for the prospective and randomised trial studies closely approximate ORs and we refer to both as ORs in this paper.) For all analyses, the most fully adjusted multivariate odds ratios were used. The fixed-effects and random effects summary $\mathrm{LOR}_{1} \mathrm{~s}$ were calculated by standard methods (DerSimonian and Laird, 1986; Fleiss, 1986). For all tables, we only present the fixedeffects $\mathrm{LOR}_{1} \mathrm{~s}$ and provide two-sided $P$-values for heterogeneity as $P_{\text {het }}$. All analyses including funnel plots (Begg and Mazumdar, 1994; Egger et al, 1997) were conducted using the meta and metabias commands in STATA (Stata Corporation, College Station, TX, USA).

The Women's Health Initiative (WHI) trial (Chlebowski et al, 2003) found, based on an intent-to-treat analysis, an average odds ratio (AOR) of invasive breast cancer of 1.24 for EPT use after an average of 5.6 years of follow-up. To convert this 1.24 figure into an $\mathrm{OR}_{1}$, we proceeded as follows: writing the instantaneous $\mathrm{OR}$ at the end of $d$ years of use as $\mathrm{OR}_{d}$, then the AOR up to the end of year $t, \mathrm{AOR}_{t}$, is the integral of the $\mathrm{OR}_{d}$ 's with $d$ taking all values from 0 through $t$ divided by the cumulative standardised risk in women not exposed to EPT, that is, $t$. This can be shown to result in the following equation:

$$
\mathrm{AOR}_{5.6}=1.24=\left[\left(\mathrm{OR}_{1}^{5.6}-1\right) / \ln \left(\mathrm{OR}_{1}\right)\right] / 5.6
$$

Solving this equation gives $\mathrm{OR}_{1}=1.080$.

For cohort studies, the true duration of EPT use is underestimated in current hormone users. This is because EPT use is assessed at baseline but continues for an unknown proportion of individuals for at least some further period until censoring time. Therefore, an additional duration of use should be added for current hormone users in the cohort studies considered (CGHFBC, 1997; Schairer et al, 2000; Porch et al, 2002; Million Women Study, 2003; Stahlberg et al, 2004). For example, in the cohort study of Porch et al (2002), they reported OR's of 1.11 and 1.76 for $<5$ and $\geqslant 5$ years of EPT use. We considered these categories as referring to 2.5 and 7.5 years of EPT use. Using these duration figures, we estimated $\mathrm{OR}_{1}$ as 1.079 . But the ORs of 1.11 and 1.76 do not relate to 2.5 and 7.5 years of use, but to this amount of use plus the mean duration of use after recruitment to the study until the end of follow-up. The mean length of follow-up in this study was 5.9 years and assuming that current users of EPT remained users during follow-up, this changes the values to be used in estimating $\mathrm{OR}_{1}$ from 2.5 and 7.5 years to 5.45 (2.5 plus the midpoint of the average follow-up, i.e. 5.9/2 or the average exposure during follow-up) and $10.45(7.5+5.9 / 2)$ years, respectively. This changes our estimate of $\mathrm{OR}_{1}$ from 1.079 to 1.052 , a $34 \%$ decline in our estimate of excess risk. This is, of course, a slight exaggeration of the change since some current users at baseline will stop use during follow-up. For all cohort studies included in the analysis, we calculated risk per year of use based on this conservative method. We applied this method to all prospective studies reporting risk for current EPT use except for the study by Schairer et al (2000), in which this adjustment had already been applied.

Risk estimates reported in the study by Magnusson et al (1999) were converted to risks per year of use since the $\mathrm{OR}_{1}$ s reported in the study excluded never users of EPT. This was done in order for these estimates to be comparable to the relative risks reported in the other studies.

\section{RESULTS}

The studies included in at least one of the three analyses conducted to evaluate EPT and breast cancer risk are given in Appendix A. A summary table of the general characteristics and overall findings for each study are presented in Appendix B. As is apparent in the summary table, the effect of EPT use by duration of use in these various studies was evaluated in a wide variety of ways with categorical cutpoints, as well as per year of use.

\section{EPT and breast cancer risk}

The overall summary of the studies included in this meta-analysis (all histologic subtypes combined) showed a weighted average $\mathrm{OR}_{1}$ of 1.076. (95\% confidence interval $(\mathrm{CI})=1.070,1.082)$ for EPT use, with some evidence of heterogeneity, $P_{\text {het }}=0.074$ (Table 1, Figure 1). A funnel plot showed no evidence of publication bias. The $\mathrm{OR}_{1}$ for the US studies was $1.052(95 \% \mathrm{CI}=1.036,1.068)$; for the European studies was $1.079(95 \% \mathrm{CI}=1.073,1.085)$; and for the Scandinavian studies was $1.089(95 \% \mathrm{CI}=1.065,1.114)$ : the difference between the US studies and the European studies was highly statistically significant $(P=0.002)$ (Table 1$)$.

\section{EPT by sequential $v s$ continuous-combined schedules and breast cancer risk}

Sequential EPT use was associated with a lower $\mathrm{OR}_{1}$ than continuous-combined EPT use (Table 2). The best estimate of the overall difference between the $\mathrm{OR}_{1} \mathrm{~s}$ was $-0.015(95 \%$ $\mathrm{CI}=-0.030,0.000), P_{\text {diff }}=0.054$. The most obvious difference between the continuous-combined and sequential schedules was seen in the two Scandinavian studies (Magnusson et al, 1999; Stahlberg et al, 2004) in which the difference in $\mathrm{OR}_{1} \mathrm{~s}$ was -0.065 $(95 \% \mathrm{CI}=-0.115,-0.015), P_{\text {diff }}=0.010$. In the remaining studies the average $\mathrm{OR}_{1}$ difference was $-0.010(95 \% \mathrm{CI}=-0.026,0.006)$, $P_{\text {diff }}=0.23$; this figure essentially reflects the Million Women Study 
Table I Odds ratios per year of use $\left(O R_{I} s\right)$ of oestrogen-progestin therapy and breast cancer risk

\begin{tabular}{|c|c|c|c|}
\hline Study & Case users & $\mathrm{OR}_{\mathrm{I}}(95 \% \mathrm{Cl})$ & \\
\hline \multicolumn{4}{|l|}{ Randomised trial } \\
\hline WHI' $(2003)^{a}$ & 199 & $1.080(1.004,1.167)$ & \\
\hline \multicolumn{4}{|l|}{ Prospective studies } \\
\hline Stahlberg ${ }^{2}(2004)^{a, b}$ & 95 & $1.097(1.068,1.127)$ & \\
\hline $\operatorname{MWS}^{3}(2003)^{\mathrm{a}, \mathrm{c}}$ & |89| & $1.077(1.071,1.084)$ & \\
\hline $\operatorname{Porch}^{4}(2002)^{a, b, c}$ & 164 & $1.052(1.022,1.084)$ & \\
\hline Schairer ${ }^{5}(2000)^{\mathrm{a}, \mathrm{d}}$ & 75 & $1.060(0.998,1.150)$ & \\
\hline \multicolumn{4}{|l|}{ Case-control studies } \\
\hline Kirsh $^{6}(2002)^{b, c}$ & 43 & $1.15(1.01,1.33)$ & \\
\hline $\mathrm{Newcomb}^{7}(2002)^{c}$ & 215 & $1.04(1.01,1.08)$ & \\
\hline Weiss $^{8}(2002)$ & 195 & $1.065(1.019,1.114)$ & \\
\hline $\operatorname{Ross}^{9}(2000)^{b}$ & 425 & $1.044(1.014,1.077)$ & \\
\hline Magnusson $^{10}(1999)^{b}$ & 399 & $1.104(1.073,1.136)$ & \\
\hline \multicolumn{4}{|l|}{ Pooled studies } \\
\hline CGHFBC $^{\prime 1}(1997)^{\mathrm{a}, \mathrm{e}}$ & 194 & $1.058(0.996,1.124)$ & \\
\hline Summary & & Pooled estimate & \\
\hline All studies & & $1.076(1.070,1.082)$ & $P_{\text {het }}=0.074$ \\
\hline US studies, 4-9,1। & & $1.052(1.036,1.068)$ & $P_{\text {het }}=0.87$ \\
\hline European studies $2,3,10$ & & $1.079(1.073,1.085)$ & $P_{\text {het }}=0.12$ \\
\hline Scandinavian studies ${ }^{2,10}$ & & $1.089(1.065,1.114)$ & $P_{\text {het }}=0.32$ \\
\hline
\end{tabular}

Abbreviations: $\mathrm{Cl}=$ confidence interval; $\mathrm{OR}=$ odds ratio; $\mathrm{WHI}=$ Women's Health Initiative; $M W S=$ Million Women Study; $C G H F B C=$ Collaborative Group on

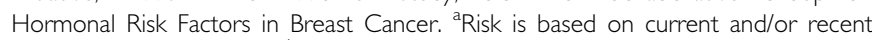
use rather than total use. ${ }^{b}$ Results included (or did not specifically exclude) in situ breast cancer cases. ${ }^{C}$ Results included (or did not specifically exclude) women with unknown age at menopause due to simple hysterectomy. ${ }^{d}$ Calculated number of cases for women with known age at menopause: $80 \%$ of the total number of cases ( $n=93)$. ${ }^{e}$ Includes mostly US studies.

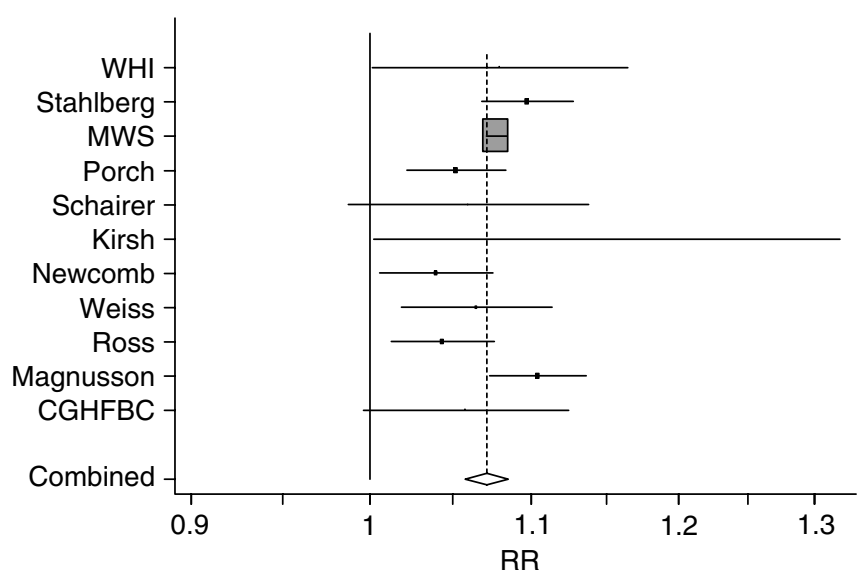

Figure I Studies included in overall analysis of EPT and risk of breast cancer: odds ratios with $95 \%$ Cls per year of use.

(2003) in which the difference was -0.013 whereas the remaining two studies (Ross et al, 2000; Weiss et al, 2002) had differences of -0.056 and 0.050 .

\section{EPT and lobular $v s$ ductal breast cancer risk}

Two of the four studies evaluating the difference in risk between lobular and ductal breast carcinoma found no difference by histology while the other two studies observed a slightly increased risk for lobular carcinoma (Table 3). The overall difference in risk (at one year) by histologic subtype was $0.019(95 \% \mathrm{CI}=-0.033$, $0.071), P_{\text {diff }}=0.47$.

\section{Current/recent use vs total lifetime use and breast cancer risk}

Only three studies (Magnusson et al, 1999; Weiss et al, 2002; Million Women Study, 2003) reported results comparing risk for past $v s$ current HT use. Pooled estimates for these three studies showed that the difference in $\mathrm{OR}_{1} \mathrm{~s}$ was -0.067 (95\% CI $=-0.081$, $-0.053), P_{\text {diff }}<0.001$ (Table 4 ). In the study by Weiss et al (2002), the only study to report risk separately for past and current EPT use, the difference was $-0.100(-0.166,-0.034), P_{\text {diff }}=0.003$.

As another way to assess potential difference in risk by recency of use, we calculated pooled estimates for those studies reporting relative risks among current/and or recent EPT use (CGHFBC, 1997; Schairer et al, 2000; Porch et al, 2002; Chlebowski et al, 2003; Million Women Study, 2003; Stahlberg et al, 2004) and compared them to pooled estimates for the studies reporting risk for lifetime EPT use (Magnusson et al, 1999; Ross et al, 2000; Kirsh and Kreiger, 2002; Newcomb et al, 2002; Weiss et al, 2002). The pooled estimate (data not shown) for the studies assessing current/recent use was slightly higher $\left(\mathrm{OR}_{1}=1.077,95 \% \mathrm{CI}=1.071,1.083\right)$ than the pooled estimate for studies reporting lifetime EPT use $\left(\mathrm{OR}_{1}=1.053,95 \% \mathrm{CI}=1.034,1.072\right)$, and this difference was statistically significant, $P_{\text {diff }}=0.019$. This difference remained significant even after excluding the Scandinavian studies (Magnusson et al, 1999; Stahlberg et al, 2004): the weighted average $\mathrm{OR}_{1}$ for current/recent use was $1.076(95 \% \mathrm{CI}=1.070,1.082)$ and 1.049 $(95 \% \mathrm{CI}=1.028,1.070)$ for lifetime use, $P_{\text {diff }}=0.017$.

\section{DISCUSSION}

The literature evaluating EPT and breast cancer risk is generally very consistent; all studies reported an increased risk of breast cancer with increasing duration of EPT use. The overall evidence showed a statistically significant increased risk of $7.6 \%$ per year of use. The risk was statistically significantly lower in US studies than in European studies - 5.2 vs $7.9 \%$.

The US figure should probably be increased slightly since the results we used for the WHI trial (Chlebowski et al, 2003) are almost certainly an underestimate of the true effect in that trial. We used the result obtained from their intent-to-treat analysis. The results from their drug-as-taken analysis was double that obtained from the intent-to-treat analysis. The WHI trial result has, however, only a small effect on the overall risk for US studies as it is associated with a wide CI. The results of the Scandinavian study of Stahlberg et al (2004) are likewise likely to be an underestimate, although to a smaller extent than with the WHI, as the authors only adjusted for age at menopause as $<55$ and $\geqslant 55$ years.

The overall within-study difference between sequential $v s$ continuous-combined EPT was $-0.015(95 \% \mathrm{CI}=-0.030,0.000)$, $P_{\text {diff }}=0.054$. This difference was due to the two Scandinavian studies (Magnusson et al, 1999; Stahlberg et al, 2004) where the risk was $-0.065(95 \% \mathrm{CI}=-0.115,-0.015), P_{\text {diff }}=0.010$. This difference was also supported by the results of the Scandinavian study reported by Jernstrom et al (2003), which we excluded earlier since the authors only presented results for continuouscombined EPT use; the authors reported their results in this manner because of the greater observed effect for continuouscombined than for sequential EPT use.

In the US, the most common form of sequential EPT provides 5-10 mg of medroxyprogesterone acetate (MPA) per day for 10 days per 28-day cycle, whereas subjects assigned to receive continuous-combined EPT are typically given $2.5 \mathrm{mg}$ of MPA every day. The total doses for sequential and continuous-combined 
Table 2 Odds ratios per year of use $\left(\mathrm{OR}_{1} \mathrm{~s}\right)$ of oestrogen-progestin therapy and breast cancer risk by progestin schedule

\begin{tabular}{|c|c|c|c|c|c|}
\hline \multirow[b]{2}{*}{ Study } & \multicolumn{2}{|c|}{ Sequential } & \multicolumn{2}{|c|}{ Continuous } & \multirow[b]{2}{*}{ Difference } \\
\hline & Case users & $\mathrm{OR}_{\mathrm{I}}(95 \% \mathrm{Cl})$ & Case users & $\mathrm{OR}_{\mathrm{I}}(95 \% \mathrm{Cl})$ & \\
\hline Stahlberg et al ${ }^{2}(2004)^{a, b}$ & 29 & $1.063(1.024,1.103)$ & 20 & $1.137(1.093,1.182)$ & $-0.074(-0.134,-0.014)$ \\
\hline MWS $^{3}(2003)^{a, c}$ & 1181 & $1.093(1.083,1.103)$ & 631 & $1.106(1.093,1.120)$ & $-0.013(-0.030,0.004)$ \\
\hline \multicolumn{6}{|l|}{ Case-control studies } \\
\hline Magnusson ${ }^{10}(1999)^{b}$ & 102 & $1.088(1.022,1.158)$ & 135 & $1.132(1.072,1.197)$ & $-0.044(-0.136,0.048)$ \\
\hline \multirow{3}{*}{$\begin{array}{l}\text { Summary } \\
\text { All studies }\end{array}$} & & Pooled estimate & & Pooled estimate & Pooled estimate \\
\hline & & $1.089(1.080,1.098)$ & & $1.103(1.092,1.115)$ & $-0.015(-0.030,0.000)$ \\
\hline & & $P_{\text {het }}=0.20$ & & $P_{\text {het }}=0.002$ & $P_{\text {diff }}=0.054$ \\
\hline US studies ${ }^{8,9}$ & & $1.057(1.022,1.093)$ & & $1.038(1.002,1.076)$ & $+0.020(-0.031,0.07 \mid)$ \\
\hline Scandinavian studies 2,10 & & $P_{\text {het }}=0.53$ & & $P_{\text {het }}=0.92$ & $P_{\text {diff }}=0.010$ \\
\hline
\end{tabular}

Abbreviations: $\mathrm{Cl}=$ confidence interval; $\mathrm{OR}=$ odds ratio; $\mathrm{WHI}=$ Women's Health Initiative; MWS = Million Women Study; CGHFBC = Collaborative Group on Hormonal Risk

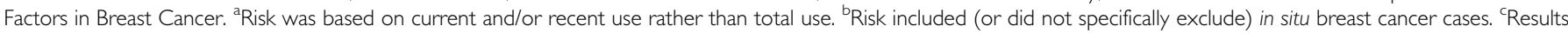
included (or did not specifically exclude) women with unknown age at menopause due to simple hysterectomy.

Table 3 Odds ratios per year of use $\left(O R_{1} s\right)$ of oestrogen-progestin therapy and breast cancer risk by histologic subtype

\begin{tabular}{|c|c|c|c|c|c|}
\hline \multirow[b]{2}{*}{ Study } & \multicolumn{2}{|c|}{ Lobular } & \multicolumn{2}{|c|}{ Ductal } & \multirow[b]{2}{*}{ Difference } \\
\hline & Case users & $\mathrm{OR}_{\mathrm{I}}(95 \% \mathrm{Cl})$ & Case users & $\mathrm{OR}_{\mathrm{I}}(95 \% \mathrm{Cl})$ & \\
\hline $\begin{array}{l}\text { Case-control studies } \\
\text { Daling }{ }^{13}(2002) \\
\text { Newcomb }^{7}(2002)^{a} \\
\text { Ursin }^{14}(2002)\end{array}$ & $\begin{array}{l}44 \\
32 \\
46\end{array}$ & $\begin{array}{l}1.096(1.007,1.193) \\
1.04(0.97,1.11) \\
1.060(0.996,1.128)\end{array}$ & $\begin{array}{l}209 \\
208 \\
291\end{array}$ & $\begin{array}{l}1.039(0.99,1.089) \\
1.04(1.00,1.08) \\
1.049(1.016,1.084)\end{array}$ & $\begin{array}{l}0.057(-0.048,0.162) \\
0.000(-0.109,0.109) \\
0.011(-0.063,0.085)\end{array}$ \\
\hline Summary & & $\begin{array}{c}\text { Pooled estimate } \\
1.067(1.026,1.110) \\
P_{\text {het }}=0.53\end{array}$ & & $\begin{array}{c}\text { Pooled estimate } \\
1.046(1.023,1.069) \\
P_{\text {het }}=0.56\end{array}$ & $\begin{array}{c}\text { Pooled estimate } \\
0.019(-0.033,0.07 \mathrm{I}) \\
P_{\text {diff }}=0.47\end{array}$ \\
\hline
\end{tabular}

Abbreviations: $\mathrm{Cl}=$ confidence interval; $\mathrm{OR}=$ odds ratio; $\mathrm{WHI}=$ Women's Health Initiative; MWS = Million Women Study; CGHFBC = Collaborative Group on Hormonal Risk Factors in Breast Cancer. ${ }^{a}$ Results included (or did not specifically exclude) women with unknown age at menopause due to simple hysterectomy. ${ }^{b}$ Risk was based on current and/or recent use rather than total use. 'Risk among lean women, lobular/ductal vs ductal only, results included (or did not specifically exclude) in situ breast cancer.

are therefore very close at approximately 75 and $70 \mathrm{mg}$ respectively per cycle. In contrast, in Scandinavia, the total dose of the progestin is much higher with continuous-combined than with sequential EPT, at least for two commonly prescribed regimens using norethisterone acetate (NETA). In these regimens, the same daily dose of NETA, $1 \mathrm{mg}$, is used with both the sequential and the continuous-combined EPT, so that the total NETA dose per cycle is roughly 10 and $28 \mathrm{mg}$ respectively. The situation in the UK is more like that in the US, with the continuous-combined regimens using lower daily progestin doses than that used in the sequential regimens, so that total progestin doses are not that different. This would be in agreement with the results found by the Million Women Study (2003).

Some of the difference in the risks found between the US studies and the European studies are due to the higher risks found with sequential regimens in Scandinavia and likely due to higher total doses of progestin (as described above). The remainder may be due to the much greater use of NETA and norgestrel in Europe.
Based on its effects in the endometrium (Dickey and Stone, 1976; Back et al, 1981; Stanczyk, 2002), the progestin dose of NETA as commonly prescribed is possibly 1.5-2.0 times the effective dose of progestin used in the US. There is also the possibility that the different types and doses of oestrogen used have different effects. Finally, some of the differences in risk may be due to a greater relative effect of HT use on breast cancer risk among leaner women. The women in the US studies in this meta-analysis are in general heavier than the women in the European studies, consistent with overall population demographics. In this meta-analysis we did not assess differences in risk by weight as only two studies evaluated risk with duration of EPT use (Schairer et al, 2000; Ursin et al, 2002) and the study of Ursin et al with much larger numbers found no differential effect of BMI; the others only gave results with duration of HT use (Magnusson et al, 1999), or with ever HT or EPT use (CGHFBC, 1997; Newcomb et al, 2002; Ursin et al, 2002; Weiss et al, 2002; Million Women Study, 2003). 


\begin{tabular}{|c|c|c|c|c|c|}
\hline \multirow[b]{2}{*}{ Study } & \multicolumn{2}{|c|}{ Past } & \multicolumn{2}{|c|}{ Current } & \multirow[b]{2}{*}{ Difference } \\
\hline & Case users & OR $(95 \% \mathrm{Cl})$ & Case users & OR $(95 \% \mathrm{Cl})$ & \\
\hline \multicolumn{6}{|l|}{ Prospective studies } \\
\hline $\operatorname{MWS}^{3}(2003)^{\mathrm{a}}$ & 1005 & $1.010(0.998,1.023)$ & $|89|$ & $1.077(1.07 \mid, 1.084)$ & $-0.067(-0.08 \mathrm{I},-0.053)$ \\
\hline \multicolumn{6}{|l|}{ Case-control studies } \\
\hline Weiss $^{8}(2002)$ & 187 & $0.947(0.892,1.005)$ & 502 & $1.047(1.013,1.083)$ & $-0.100(-0.166,-0.034)$ \\
\hline $\begin{array}{l}\text { Summary } \\
\text { All studies }\end{array}$ & & $\begin{array}{c}\text { Pooled estimate } \\
\text { I.01। }(0.999,1.023) \\
P_{\text {het }}=0.011\end{array}$ & & $\begin{array}{c}\text { Pooled estimate } \\
\text { I.079 }(1.073,1.085) \\
P_{\text {het }}<0.001\end{array}$ & $\begin{array}{c}\text { Pooled estimate } \\
-0.069(-0.082,-0.055) \\
P_{\text {diff }}<0.000 \text { I }\end{array}$ \\
\hline
\end{tabular}

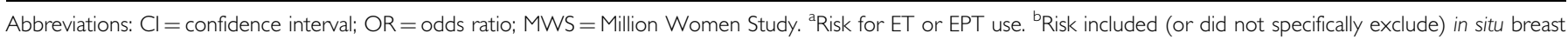
cancer cases.

Summary risk estimates by histology were higher for lobular than for ductal carcinoma; the $\mathrm{OR}_{1}$ difference was 0.019 , but this was not statistically significant. Further data are needed on this issue.

Schairer et al (2000) reported much higher estimates than the other studies for both lobular $\left(\mathrm{OR}_{1}=1.17\right)$ and ductal carcinoma $\left(\mathrm{OR}_{1}=1.17\right)$. These risks compare to their overall result (Table 1) of an $\mathrm{OR}_{1}$ of 1.076. The explanation is that the authors only provided results by histology among lean women, and in their study the effect of EPT on risk was much greater in lean women.

Only the study by Weiss et al (2002) compared risk for current $v s$ past EPT use. Their results suggest that risk for current EPT use is higher. The Million Women Study (2003) compared current HT use and past EPT use, and the study by Magnusson et al (1999) compared current and past HT use. The results from these two studies are difficult to interpret since HT use in past users includes proportionately more ET use. We found that recent EPT use was associated with a higher risk than lifetime EPT use, but this analysis was based on only a small number of studies.

The observed lower risk with past use may be due, at least in part, to the fact that that duration of hormone use is not measured

\section{REFERENCES}

Back DJ, Bates M, Breckenridge AM, Hall JM, MacIver M, Orme ML, Park BK, Rowe PH (1981) The pharmacokinetics of levonorgestrel and ethynylestradiol in women - studies with Ovran and Ovranette. Contraception 23: 229-239

Begg CB, Mazumdar M (1994) Operating characteristics of a rank correlation test for publication bias. Biometrics 50: 1088-1101

Chen CL, Weiss NS, Newcomb P, Barlow W, White E (2002) Hormone replacement therapy in relation to breast cancer. JAMA 287: 734-741

Chlebowski RT, Hendrix SL, Langer RD, Stefanick ML, Gass M, Lane D, Rodabough RJ, Gilligan MA, Cyr MG, Thomson CA, Khandekar J, Petrovitch H, McTiernan A (2003) Influence of estrogen plus progestin on breast cancer and mammography in healthy postmenopausal women: the Women's Health Initiative Randomized Trial. JAMA 289: 3243 - 3253

Collaborative Group on Hormonal Factors in Breast Cancer (1997) Breast cancer and hormone replacement therapy: collaborative reanalysis of data from 51 epidemiological studies of 52705 women with breast cancer and 108411 women without breast cancer. Lancet 350: 1047-1059

Daling JR, Malone KE, Doody DR, Voigt LF, Bernstein L, Coates RJ, Marchbanks PA, Norman SA, Weiss LK, Ursin G, Berlin JA, Burkman RT, Deapen D, Folger SG, McDonald JA, Simon MS, Strom BL, Wingo PA, Spirtas R (2002) Relation of regimens of combined hormone replacement therapy to lobular, ductal, and other histologic types of breast carcinoma. Cancer 95: 2455-2464

DerSimonian R, Laird N (1986) Meta-analysis in clinical trials. Control Clin Trials 7: $177-188$

Dickey RP, Stone SC (1976) Progestational potency of oral contraceptives. Obstet Gynecol 47: $106-112$ the same in current as in past hormone users. The actual duration of use within a duration category will tend to be longer in current than in past users (Ettinger et al, 2003), and, in cohort studies, duration of use is underestimated in current users since exposure is only assessed at baseline. Nondifferential misclassification of duration of use is also likely to be higher with past use, leading to a greater underestimate of the risk associated with past use. Four of the five studies reporting risk among current/recent users addressed the possibility that a screening bias could be a possible explanation for the observed lower risk among past users (Schairer et al, 2000; Porch et al, 2002; Rossouw et al, 2002; Chlebowski et al, 2003; Million Women Study, 2003). None found any evidence of this.

\section{ACKNOWLEDGEMENTS}

This work was supported by Grants CA14089 and CA54281 from the National Cancer Institute. We would like to thank Ms Peggy Wan for much computing assistance with this analysis.
Egger M, Davey Smith G, Schneider M, Minder C (1997) Bias in metaanalysis detected by a simple, graphical test. $\mathrm{Br}$ Med J 315: 629-634

Ettinger B, Grady D, Tosteson AN, Pressman A, Macer JL (2003) Effect of the Women's Health Initiative on women's decisions to discontinue postmenopausal hormone therapy. Obstet Gynecol 102: 1225-1232

Fleiss JL (1986) Analysis of data from multiclinic trials. Control Clin Trials 7: $267-275$

Jernstrom H, Bendahl PO, Lidfeldt J, Nerbrand C, Agardh CD, Samsioe G (2003) A prospective study of different types of hormone replacement therapy use and the risk of subsequent breast cancer: the women's health in the Lund area (WHILA) study (Sweden). Cancer Causes Control 14: 673-680

Kirsh V, Kreiger N (2002) Estrogen and estrogen-progestin replacement therapy and risk of postmenopausal breast cancer in Canada. Cancer Causes Control 13: 583-590

Li CI, Malone KE, Porter PL, Weiss NS, Tang MT, Cushing-Haugen KL, Daling JR (2003) Relationship between long durations and different regimens of hormone therapy and risk of breast cancer. JAMA 289: $3254-3263$

Li CI, Weiss NS, Stanford JL, Daling JR (2000) Hormone replacement therapy in relation to risk of lobular and ductal breast carcinoma in middle-aged women. Cancer 88: $2570-2577$

Li R, Gilliland FD, Baumgartner K, Samet J (2002) Hormone replacement therapy and breast carcinoma risk in Hispanic and non-Hispanic women. Cancer 95: 960-968

Magnusson C, Baron JA, Correia N, Bergstrom R, Adami HO, Persson I (1999) Breast-cancer risk following long-term oestrogen- and oestrogen-progestin-replacement therapy. Int J Cancer 81: 339-344 
Million Women Study (2003) Breast cancer and hormone-replacement therapy in the Million Women Study. Lancet 362: 419-427

Moorman PG, Kuwabara H, Millikan RC, Newman B (2000) Menopausal hormones and breast cancer in a biracial population. Am J Public Health 90: $966-971$

Newcomb PA, Titus-Ernstoff L, Egan KM, Trentham-Dietz A, Baron JA, Storer BE, Willett WC, Stampfer MJ (2002) Postmenopausal estrogen and progestin use in relation to breast cancer risk. Cancer Epidemiol Biomarkers Prev 11: 593-600

Newcomer LM, Newcomb PA, Potter JD, Yasui Y, Trentham-Dietz A, Storer BE, Longnecker MP, Baron JA, Daling JR (2003) Postmenopausal hormone therapy and risk of breast cancer by histologic type (United States). Cancer Causes Control 14: 225-233

Olsson HL, Ingvar C, Bladstrom A (2003) Hormone replacement therapy containing progestins and given continuously increases breast carcinoma risk in Sweden. Cancer 97: $1387-1392$

Persson I, Thurfjell E, Bergstrom R, Holmberg L (1997) Hormone replacement therapy and the risk of breast cancer: nested case-control study in a cohort of Swedish women attending mammography screening. Int J Cancer 72: 758-761

Persson I, Weiderpass E, Bergkvist L, Bergstrom R, Schairer C (1999) Risks of breast and endometrial cancer after estrogen and estrogen-progestin replacement. Cancer Causes Control 10: 253-260

Persson I, Yuen J, Bergkvist L, Schairer C (1996) Cancer incidence and mortality in women receiving estrogen and estrogen-progestin replacement therapy - long-term follow-up of a Swedish cohort. Int J Cancer 67: $327-332$

Pike MC, Ross RK, Spicer DV (1998) Problems involved in including women with simple hysterectomy in epidemiologic studies measuring the effects of hormone replacement therapy on breast cancer risk. Am J Epidemiol 147: 718-721

Porch JV, Lee IM, Cook NR, Rexrode KM, Burin JE (2002) Estrogen-progestin replacement therapy and breast cancer risk: the

\section{Appendix A}

Studies evaluating oestrogen - progestin use and breast cancer risk. Studies included in each analysis are represented by an ' $x$ ' and studies excluded are marked by footnotes.
Women's Health Study (United States). Cancer Causes Control 13: $847-854$

Rockhill B, Colditz GA, Rosner B (2000) Bias in breast cancer analyses due to error in age at menopause. Am J Epidemiol 151: 404-408

Ross RK, Paganini-Hill A, Wan PC, Pike MC (2000) Effect of hormone replacement therapy on breast cancer risk: estrogen $v s$ estrogen plus progestin. J Natl Cancer Inst 92: 328-332

Rossouw JE, Anderson GL, Prentice RL, LaCroix AZ, Kooperberg C, Stefanick ML, Jackson RD, Beresford SA, Howard BV, Johnson KC, Kotchen JM, Ockene J (2002) Risks and benefits of estrogen plus progestin in healthy postmenopausal women: principal results from the Women's Health Initiative randomized controlled trial. JAMA 288: 321 - 333

Rothman KJ, Greenland S (1998) Modern Epidemiology. Philadelphia: Lippincott-Raven

Schairer C, Lubin J, Troisi R, Sturgeon S, Brinton L, Hoover R (2000) Menopausal estrogen and estrogen-progestin replacement therapy and breast cancer risk. JAMA 283: 485-491

Stahlberg C, Pedersen AT, Lynge E, Andersen ZJ, Keiding N, Hundrup YA, Obel EB, Ottesen B (2004) Increased risk of breast cancer following different regimens of hormone replacement therapy frequently used in Europe. Int I Cancer 109: 721 -727

Stanczyk FZ (2002) Pharmacokinetics and potency of progestins used for hormone replacement therapy and contraception. Rev Endocr Metab Disord 3: $211-224$

Ursin G, Tseng CC, Paganini-Hill A, Enger S, Wan PC, Formenti S, Pike MC, Ross RK (2002) Does menopausal hormone replacement therapy interact with known factors to increase risk of breast cancer? J Clin Oncol 20: $699-706$

Weiss LK, Burkman RT, Cushing-Haugen KL, Voigt LF, Simon MS, Daling JR, Norman SA, Bernstein L, Ursin G, Marchbanks PA, Strom BL, Berlin JA, Weber AL, Doody DR, Wingo PA, McDonald JA, Malone KE, Folger SG, Spirtas R (2002) Hormone replacement therapy regimens and breast cancer risk. Obstet Gynecol 100: $1148-1158$

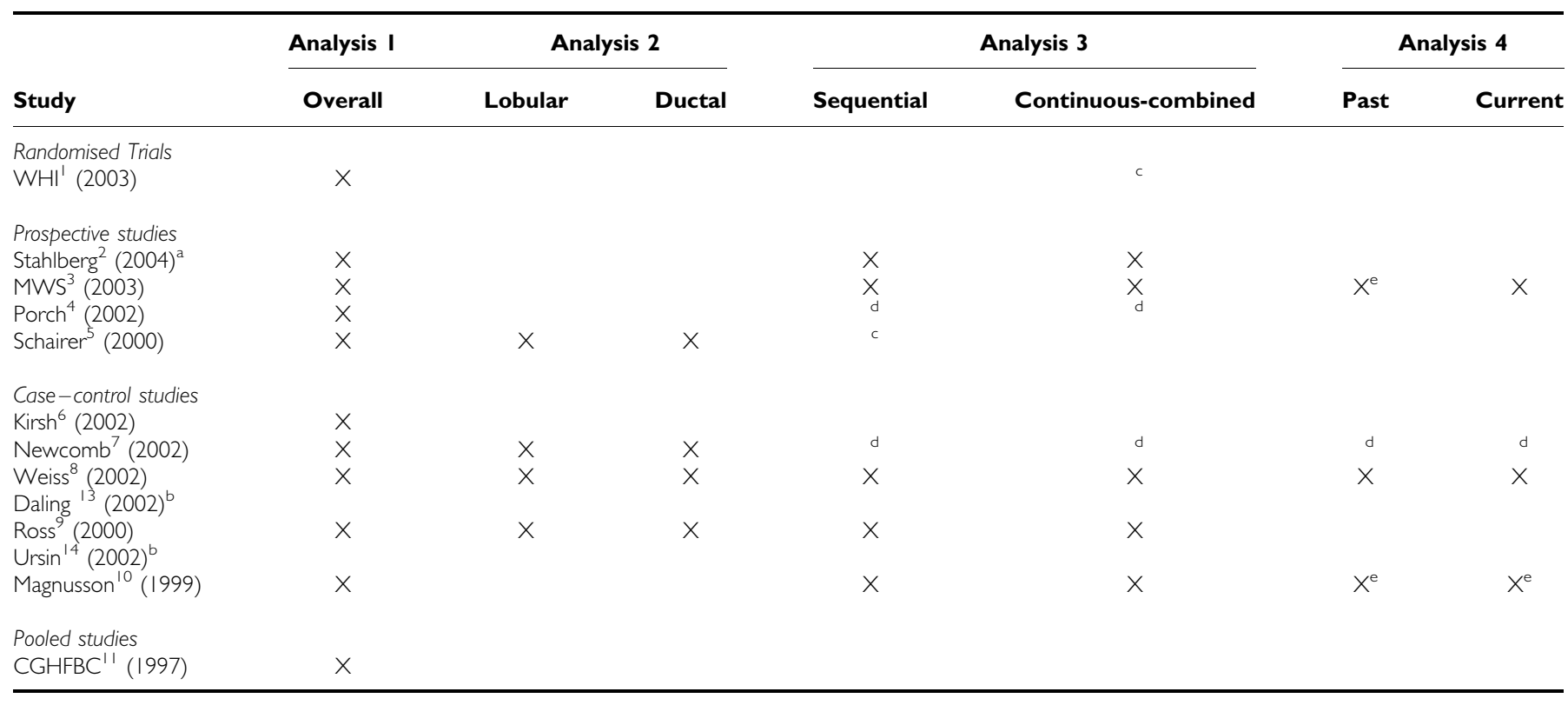

Abbreviations: $\mathrm{Cl}=$ confidence interval; $\mathrm{OR}=$ odds ratio; WHI =Women's Health Initiative; MWS = Million Women Study; CGHFBC = Collaborative Group on Hormonal Risk Factors in Breast Cancer. ${ }^{a}$ Overall risk calculated from sequential and continuous-combined use. ${ }^{b}$ Results by histologic subtype, not overall breast cancer risk (overall risk for Daling in Weiss and for Ursin in Ross). 'Only results for one type of progestin schedule. ${ }^{d}$ No results given for duration of EPT use. ${ }^{\mathrm{e}}$ Risk for ET or EPT use. 


\section{Appendix B}

Studies evaluating oestrogen - progestin use and breast cancer risk: overall characteristics and main findings.

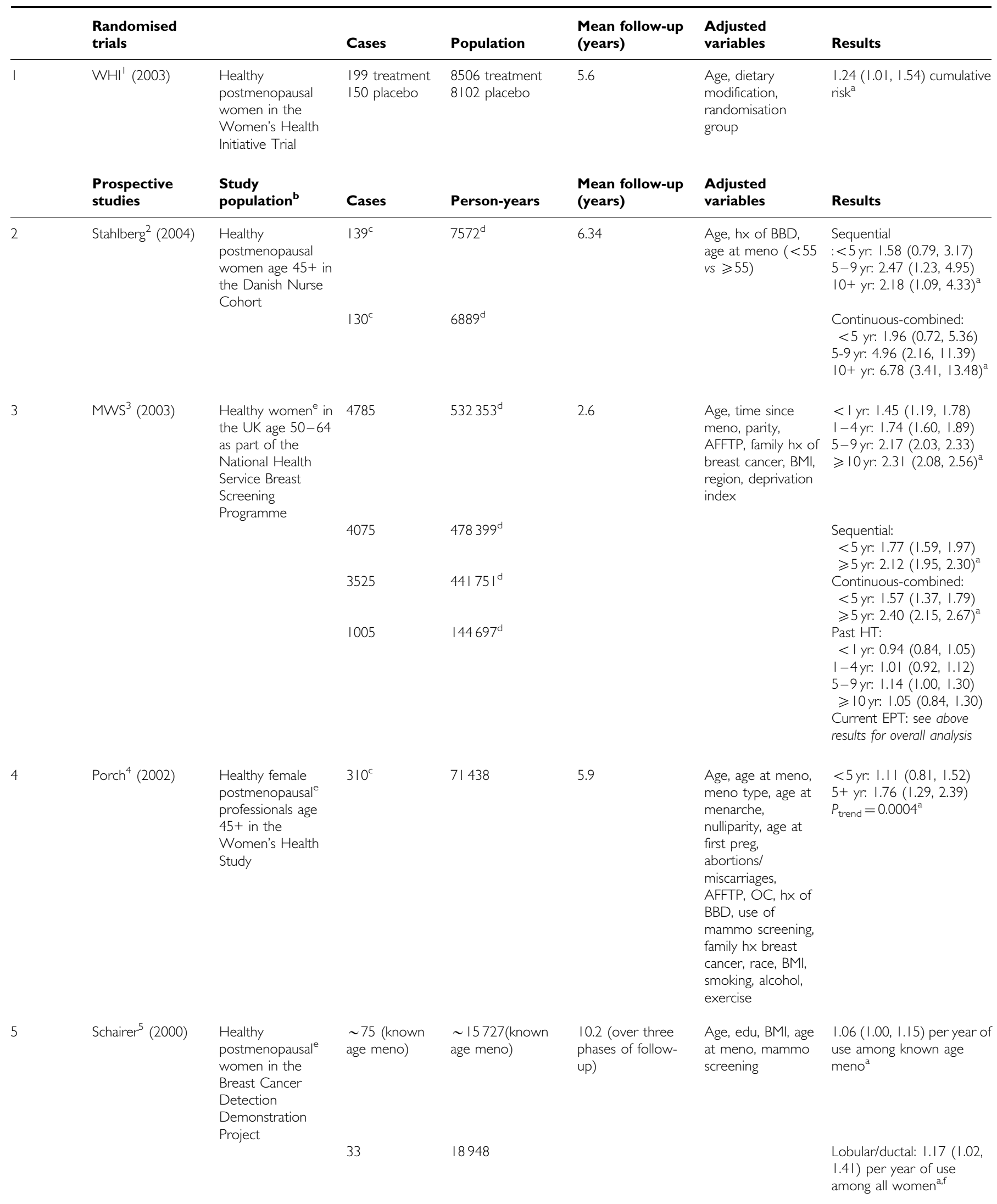


Meta-analysis of oestrogen-progestin therapy and breast cancer

Appendix B (Continued)

\begin{tabular}{|c|c|c|c|c|c|}
\hline $\begin{array}{l}\text { Prospective } \\
\text { studies }\end{array}$ & Cases & Population & $\begin{array}{l}\text { Mean follow-up } \\
\text { (years) }\end{array}$ & $\begin{array}{l}\text { Adjusted } \\
\text { variables }\end{array}$ & Results \\
\hline & 26 & 18948 & & & $\begin{array}{l}\text { ductal: I.I7 (I.02, I.4I) pe } \\
\text { year of use among all } \\
\text { women }^{a, f}\end{array}$ \\
\hline & 48 & 18948 & & & $\begin{array}{l}\text { Sequential: }(P<15 \text { days/mo }) \\
\leqslant 4 \text { yr: } 1.1(0.8,1.7) \\
>4 \text { yr: } 1.5(1.0,2.4) \\
\text { among all women }^{\mathrm{a}}\end{array}$ \\
\hline
\end{tabular}

\begin{tabular}{|c|c|c|}
\hline & $\begin{array}{l}\text { Case-control } \\
\text { studies }\end{array}$ & $\begin{array}{l}\text { Study } \\
\text { population }\end{array}$ \\
\hline 6 & Kirsh $^{6}$ (2002) & $\begin{array}{l}\text { Healthy } \\
\text { postmenopausal }^{\mathrm{e}} \\
\text { women in Ontario, } \\
\text { Canada }\end{array}$ \\
\hline 7 & Newcomb $^{7}$ (2002) & $\begin{array}{l}\text { Healthy } \\
\text { postmenopausale } \\
\text { women from } \\
\text { Massachusetts, } \\
\text { New Hampshire, } \\
\text { Wisconsin }\end{array}$ \\
\hline 8 & Weiss $^{8}$ (2002) & $\begin{array}{l}\text { Healthy black and } \\
\text { white } \\
\text { postmenopausal } \\
\text { women in Atlanta, } \\
\text { Detroit, Los } \\
\text { Angeles, } \\
\text { Philadelphia, Seattle } \\
\text { in the } \\
\text { Contraceptive and } \\
\text { Reproductive } \\
\text { Experiences } \\
\text { (CARE) Study }\end{array}$ \\
\hline
\end{tabular}

Age, race, study center, type of meno, age at meno
Adjusted variables

Age, age at meno, $\quad 1.15(1.01,1.33)$ per year of type of meno, hx of use BBD

Age at meno, type of meno, AFFTP, $\mathrm{BMI}$, family $\mathrm{hx}$ breast cancer, edu, mammo screening $\mathrm{hx}$, recent alcohol, $h x$ of BBD, age at menarche, recent physical activity

$$
\text { 1.1 } 1
$$$$
2 \text { to < } 5 \text { yr: } 1.33 \text { (0.9।, }
$$$$
\text { 1.95) }
$$$$
5+y r: 1.49(1.05,2.12)
$$

I.04 (1.01, I.08) per year of use

Lobular: 1.04 (0.97, I. I I) per year of use Ductal: 1.04 (।.00, 1.08) per year of use $>0$ to <6 mo: 0.59 (0.40 $0.87)$

6 mo to $<2$ yr: 0.82 (0.57,

$5+$ yr: $1.49(1.05,2.12)$
Sequential: $(P<25$ days/ mo)

$>0$ to $<6$ mo: 0.70 (0.38,

1.30)

6 mo to $<2$ yr: $0.72(0.42$,

1.24)

2 to $<5$ yr: $1.44(0.79$,

2.6I)

$5+$ yr: $1.18(0.70,1.98)$

Continuous-combined:

$(P \geqslant 25$ days $/ \mathrm{mo})$

$>0$ to <6 mo: $0.58(0.36$

0.94)

6 mo to $<2$ yr: I. I । (0.7।

1.75)

2 to $<5$ yr: $1.38(0.86$,

2.22)

5+ yr: $1.77(1.04,3.01)$

Past EPT

:>0 to < 6 mo: 0.68 (0.47, 0.99 )

6 mo to $<2$ yr: $0.76(0.52$,

1.13)

2 to $<5$ yr: 1.24 (0.79,

1.93)

$5+$ yr: $0.54(0.33,0.88)$

Current EPT:

$>0$ to $<6$ mo: 0.53

$(0.26,1.09)$ 
Appendix B (Continued)

\begin{tabular}{|c|c|c|c|c|c|c|c|}
\hline & $\begin{array}{l}\text { Case-control } \\
\text { studies }\end{array}$ & & Cases & Population & $\begin{array}{l}\text { Mean follow-up } \\
\text { (years) }\end{array}$ & $\begin{array}{l}\text { Adjusted } \\
\text { variables }\end{array}$ & Results \\
\hline & & & & & & & $\begin{array}{l}6 \text { mo to }<2 \text { yr: } 1.11(0.75, \\
1.65) \\
2 \text { to }<5 \text { yr: } 1.28(0.95 \\
1.73) \\
5+\text { yr: } 1.37(1.06,1.77)\end{array}$ \\
\hline & & & 635 & 835 & & & $\begin{array}{l}\text { Ductal: } \\
\leqslant 6 \text { mo: } 0.6(0.4,0.9) \\
6 \text { mo to } 5 \text { yr: } 1.0(0.7,1.3) \\
5 y r+: 1.3(0.9,1.9)\end{array}$ \\
\hline \multirow[t]{4}{*}{9} & $\operatorname{Ross}^{9}(2000)$ & $\begin{array}{l}\text { Healthy } \\
\text { postmenopausal } \\
\text { women in Los } \\
\text { Angeles }\end{array}$ & $1298^{c}$ & 1108 & & $\begin{array}{l}\text { Type of meno, age } \\
\text { at meno, age at } \\
\text { menarche, family hx } \\
\text { of breast cancer, } \\
\text { history BBD, } \\
\text { nulliparity, AFFTP, } \\
\text { OCs, BMI, alcohol }\end{array}$ & $\begin{array}{l}1.24(1.07,1.45) \text { per } 5 \text { yr of } \\
\text { use } \\
P_{2 \text {-sided }}=0.005\end{array}$ \\
\hline & & & $1193^{c}$ & 1012 & & & $\begin{array}{l}\text { Sequential: }(P<\text { entire } \\
\text { cycle) } \\
\text { I.38 }(1.13,1.68) \\
P_{2 \text {-sided }}=0.0015\end{array}$ \\
\hline & & & $978^{c}$ & 880 & & & $\begin{array}{l}\text { Continuous-combined: } \\
(P=\text { entire cycle }) \\
1.09(0.88,1.35) \\
P_{\text {2-sided }}=0.44\end{array}$ \\
\hline & $U_{r s i n}{ }^{14}(2002)$ & & 164 & 1637 & & $\begin{array}{l}\text { Type and age at } \\
\text { meno, age at } \\
\text { menarche, family hx } \\
\text { breast cancer, hx of } \\
\text { BBD, nulliparity, } \\
\text { AFFTP, OCs, } \\
\text { weight, alcohol }\end{array}$ & $\begin{array}{l}\text { Lobular: } 1.34(0.98,1.83) \\
\text { per } 5 \text { yr of use } \\
P_{\text {trend }}=0.06\end{array}$ \\
\hline \multirow{3}{*}{10} & & & $|84|^{c}$ & 2272 & & & $\begin{array}{l}\text { Sequential: }(P<16 \text { days/ } \\
\text { mo }) \\
\text { I-24 mo: I.58 ( } 1.01,2.46) \\
25-60 \text { mo: } 1.34(0.71, \\
2.54) \\
60-120 \text { mo: } 1.89(0.88, \\
4.09) \\
>120 \text { mo: } 2.45(0.82, \\
7.30)\end{array}$ \\
\hline & & & $1874^{c}$ & 2322 & & & $\begin{array}{l}\text { Continuous-combined: } \\
(P \geqslant 19 \text { days } / \mathrm{mo}) \\
1-24 \mathrm{mo}: 0.93(0.63,1.36) \\
25-60 \mathrm{mo}: 1.26(0.76, \\
2.09) \\
60-120 \mathrm{mo:} 2.89(1.66, \\
5.00) \\
>120 \mathrm{mo}: 5.36(1.47, \\
19.56)\end{array}$ \\
\hline & & & $1828^{c}$ & 2302 & & & 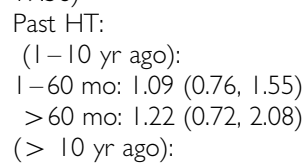 \\
\hline
\end{tabular}


Meta-analysis of oestrogen-progestin therapy and breast cancer

SA Lee et al

Appendix B (Continued)

\begin{tabular}{|c|c|c|c|c|c|c|c|}
\hline & $\begin{array}{l}\text { Case-control } \\
\text { studies }\end{array}$ & & Cases & Population & $\begin{array}{l}\text { Mean follow-up } \\
\text { (years) }\end{array}$ & $\begin{array}{l}\text { Adjusted } \\
\text { variables }\end{array}$ & Results \\
\hline & & & $2182^{c}$ & 2475 & & & $\begin{array}{l}\text { I-60 mo: } 1.24(0.90,1.70) \\
>60 \text { mo: } 2.57(1.28,5.15) \\
\text { Current HT (< I yr ago): } \\
\text { I - } 60 \text { mo: } 1.52(1.21,1.92) \\
>60 \text { mo: } 2.68(2.09,3.42)\end{array}$ \\
\hline & Pooled analysis & $\begin{array}{l}\text { Study } \\
\text { population* }\end{array}$ & Cases & Controls & & $\begin{array}{l}\text { Adjusted } \\
\text { variables }\end{array}$ & Results \\
\hline | | & CGHFBC $^{\prime \prime}$ (1997) & $\begin{array}{l}\text { Women from } 22 \\
\text { published and two } \\
\text { unpublished studies } \\
\text { with information on } \\
\text { type of preparation } \\
\text { (EPT, ET, PT) }\end{array}$ & 12611 & 23866 & & $\begin{array}{l}\text { Study, age at } d x \text { or } \\
\text { pseudo } d x \text {, time } \\
\text { since meno, BMI, } \\
\text { parity, AFFTP }\end{array}$ & $\begin{array}{l}<5 \text { yr: } 1.15(\text { s.e. }=0.19) \\
\geqslant 5 \text { yr: } 1.53(\text { s.e. }=0.33)^{a}\end{array}$ \\
\hline
\end{tabular}

Abbreviations: WHI =Women's Health Initiative; MWS = Million Women Study; CGHFBC = Collaborative Group on Hormonal Risk Factors in Breast Cancer; OC = ora contraceptives; $\mathrm{hx}=$ history; $\mathrm{BBD}=$ benign breast disease; $\mathrm{BMI}=$ body mass index, preg = pregnancy; mammo= mammography; edu=education level; meno = menopause; $\mathrm{AFFTP}=$ age at first full-term pregnancy; $\mathrm{dx}=$ diagnosis; $\mathrm{mo}=$ month(s); yr=year(s); $\mathrm{P}=$ progestin; $\mathrm{E}=$ oestrogen; s.e. = standard error. ${ }^{\mathrm{a}}$ Risk was based on current and/or recent use rather than total use. ${ }^{b}$ Number of cases and number of starting population/person-years/controls for the results presented in final column. ${ }^{\mathrm{C}}$ Results included (or did not specifically exclude) in situ breast cancer cases. ${ }^{d}$ Authors provided population rather than person-years. ${ }^{e}$ Results included (or did not specifically exclude) women with

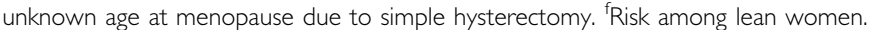

